\title{
CD19 CAR-T cell therapy for relapsed /refractory acute lymphoblastic leukemia: factors affecting toxicities and long-term efficacies
}

\author{
Li-Na Zhang, Yongping Song ${ }^{*}$ and Delong Liu ${ }^{*}$ (D)
}

\begin{abstract}
The prognosis of adults with relapsed/refractory (R/R) acute lymphoblastic leukemia (ALL) remains dismal even at this day and age. With salvage chemotherapy, only 29\% (range 18 to 44\%) of the patients with R/R ALL can be induced into complete remission (CR), with a median overall survival (OS) of 4 months (range 2-6 months). Blinatumomab and inotuzumab ozogamycin $(\mathrm{IO})$ are immunotherapeutic agents that increased CR to $80 \%$ and extended survival to 7 . 7 months in this high-risk population of patients. In the last few years, chimeric antigen receptor (CAR)--engineered T cells have led to major progress in cancer immunotherapy. CD-19 CAR-T cells have been recently approved for high-risk R/R ALL and lymphoma. The data from long-term follow-up of a single-center phase I study of 19-28z CAR-T cell therapy for adult R/R ALL were just published. At the same time, a multicenter phase II study of 19-41BB CAR-T cell therapy for children and young adults with R/R B cell ALL was also published. The two studies provided fresh information with longterm follow-up. This research highlight analyzed the data and proposed future perspectives for further investigation in this rapidly evolving field.
\end{abstract}

Keywords: Chimeric antigen receptor, CAR-T, Cancer immunotherapy, Blinatumomab

\section{Background}

The prognosis of adults with relapsed/refractory (R/R) acute lymphoblastic leukemia (ALL) remains dismal even at this day and age $[1,2]$. With salvage chemotherapy, only $29 \%$ (range 18 to $44 \%$ ) of the patients with R/R ALL can be induced into complete remission (CR), with a median overall survival (OS) of 4 months (range 2-6 months) [3-10]. Novel agents are needed to improve the therapy of R/R ALL. Blinatumomab, the first FDAapproved BiTE antibody, has been shown to extend the median survival to 7.7 months in patients with CD19+, Philadelphia chromosome $(\mathrm{Ph})$--negative $\mathrm{R} / \mathrm{R}$ ALL [11] (Table 1). Recently, inotuzumab ozogamycin (IO), a CD-22 antibody-drug conjugate, was shown to improve CR rate to $80 \%$ and overall survival to 7.7 months [12]. In the last few years, chimeric antigen receptor $(\mathrm{CAR})--$ engineered $\mathrm{T}$ cells have led to

\footnotetext{
* Correspondence: songyongping001@163.com; delong_liu@nymc.edu The affiliated Cancer Hospital of Zhengzhou University and Henan Cancer Hospital, 127 Dongming Road, Zhengzhou 450008, China
}

major progress in cancer immunotherapy [13-25]. CD-19 CAR-T cells have been well studied and recently approved by FDA for children and young adults with R/R ALL (tisagenlecleucel, kymriah ${ }^{\mathrm{Tm}}$ ) [24, 26-29]. In this population of patients, $90 \%$ of the patients were induced to $\mathrm{CR}$, yet the median follow-up was only 7 months. A second CD-19 directed CAR-T cell product was recently approved for the therapy of relapsed and/or refractory lymphoma (axicabtagene ciloleucel, yescarta $\left.{ }^{\mathrm{Tm}}\right)$ [30].

\section{9-28z CAR-T cells for R/R ALL in adults with a long-term follow-up}

The data from a long-term follow-up of a single-center phase I study of 19-28z CAR-T cell therapy for adult R/ R ALL were just published [31]. The primary endpoint of this phase I study was safety. This study had a median follow-up of 29 months (range 1-65 months), with 53 patients evaluable. The CR rate was $83 \%$, and the median OS was 12.9 months. The rate of severe cytokine 
Table 1 New agents for immunotherapy of relapsed/refractory acute lymphoblastic leukemia

\begin{tabular}{lllll}
\hline & Blin & IO & 19-28Z CAR & 19-41BB CAR \\
\hline Phase & III & III & I & I \\
Patients & & & & \\
$\quad$ Age (year) & $\geq 18$ & $\geq 18$ & $\geq 18$ & $\leq 21$ \\
$\quad$ No. enrolled & 271 & 141 & 83 & 92 \\
$\quad$ No. evaluable & 267 & 109 & 53 & 75 \\
Follow-up (m) & 11.7 & NA & 29 & 13.1 \\
CR \% & 44 & 80.7 & 83 & 81 \\
EFS (m) & 7.3 & 5 (PFS) & 6.1 & NR \\
OS (m) & 7.7 & 7.7 & 12.9 & NR \\
CRS ( $\geq$ grade III \%) & 4.9 & NA & 26 & 47 \\
Neurotoxicity \% & 9.4 & NA & 44 & 40 \\
References & 11 & 12 & 31 & 32 \\
\hline
\end{tabular}

Abbreviations: Blin blinatumomab, 10 inotuzumab ozogamycin, CAR chimeric antigen receptor, CRS cytokine release syndrome, $m$ month, $N A$ not available/applicable, NR not reached, PFS progression-free survival, $C R$ complete remission, EFS event-free survival, OS overall survival

release syndrome (CRS) was $26 \%$ (Table 1$)$. At the same time, a multicenter phase II study of 19-41BB CAR-T cell therapy for children and young adults with $R / R$ B cell ALL was also published [32]. This study had 75 evaluable patients. The median follow-up in this study was 13.1 months. The CR rate was $81 \%$. The rate of severe CRS was $77 \%[32,33]$.

\section{The patient population}

The 19-28Z CAR study enrolled a total of 83 patients over a stretch of 65 months, yet 30 patients did not receive the CAR-T therapy mainly due to the advanced disease status of the patients [31]. The 53 evaluable patients were indeed heavily pretreated: $23 \%$ with primary refractory disease, $61 \%$ had 3 or more lines of prior regimens, $36 \%$ failed prior allogeneic stem cell transplantation (alloSCT), and $25 \%$ had failed blinatumomab. Thirty percent (16 of 53) of the evaluable patients were $\mathrm{Ph}+$, with 10 of 16 already failed ponatinib. Among the 53 patients, only $6(11 \%)$ were negative for minimal residual disease (MRD) $(<0.01 \%$ bone marrow blasts) prior to CAR-T infusion.

\section{Factors affecting responses and toxicities}

Although the $83 \%$ CR rate is not particularly impressive in the $19-28 z$ study, $67 \%$ of the patients became MRDnegative [31]. It is noteworthy that the CR rate was not affected by any of the common poor-risk factors, indicating that CAR-T therapy may be able to defy conventional poor-risk factors (prior transplant history, prior regimens, conditioning regimens). Instead, disease burden and $\mathrm{Ph}$ positivity appeared to affect responses. Higher disease burden was associated with higher rate of CRS and neurotoxicity. Higher peak CAR-T cell expansion was noted to be associated with deeper responses (higher MRDnegative CR rate) but at the expense of higher rate of and more severe neurotoxicity and CRS. The study suggests that both higher disease burden and higher peak CAR-T cell expansion are independent predictors of severe neurotoxic effects.

In the 19-41BB CAR study, no relationship between peak CAR-T cell expansion and dosage of the infused CAR-T cells was observed. There was neither definitive relationship observed between dosage and response [32]. Severe CRS requiring ICU care was reported in $47 \%$ of the patients. This appeared to be higher than that observed in the 19-28z single-center study. However, the 19-41BB CAR study was an international multicenter study, and the criteria for ICU care varied widely and could potentially be responsible for the high rate of ICU care.

\section{Factors affecting relapses and long-term survival post-CAR-T therapy}

In the $19-28 \mathrm{z}$ CAR study, 32 of the 53 patients (67\%) had MRD-negative CR whereas 9 patients entered CR with still positive MRD (bone marrow blasts $>=0.01 \%$ ) post CAR-T therapy. All patients with positive MRD CR (9/9) relapsed with CD-19+ blasts, but only $50 \%$ of those with MRD negative CR (16 of the 32) had a relapse, including 4 patients who had a relapse with CD19- blasts. Among the 32 patients with MRD-negative CR, allogeneic transplantation did not lead to better survival than those who were not transplanted. Although the sample size of this study was not powered to detect the potential differences, the above observation nevertheless implies that additional graft-versus-leukemia effect may not be achieved by alloSCT after CAR-T cell infusion, and additional factors are responsible for relapses, loss of CD19 expression being a prominent one. Expression of PD-L1 was reported to be increased in those patients who became refractory to blinatumomab [34]. It is not known at this time whether this could be one of the factors responsible for relapse. It is unclear at this time whether it is beneficial to use allogeneic CAR-T cells as conditioning therapy followed immediately by allogeneic stem cell transplantation [35].

The persistence of 19-28z CAR-T cells was not found to be correlated with survival in the study. This observation may lend support to the development of newer generation of CARs that have on-off switch to control the expression of the engineered CARs $[16,19,20]$.

The 19-41BB CAR-T cells were demonstrated to be present in the peripheral blood for a median of 168 days, with ongoing persistence of 20 months. The 4-1BB costimulation domain has been suggested to be able to ameliorate $\mathrm{T}$ cell exhaustion and enhance the persistence of CAR-T cells. 
It remains unclear at this time whether prolonged persistence of the 19-41BB CAR-T cells could lead to better overall survival in the long run. In the current report with a 13.1 month median follow-up, both median event-free survival and overall survival have not been reached [32].

Neither CAR-T cell dose nor the magnitude of peak CAR-T cell expansion was associated with better survival, even though these are potential factors being associated with higher toxicities. It may be the ratio of the CART cell dose to the disease burden that is associated with better event-free and overall survival [31]. The median OS was 20.1 months among patients with low disease burden, as compared with 12.4 months among patients with a high-disease burden $(p=0.02)$. The study again confirmed the well-known phenomenon that lower disease burden is associated with better long-term survival in ALL. Great efforts should be made to achieve the lowest disease burden (MRD-negative CR) prior to CAR-T therapy as well as to alloSCT.

There have been a variety of studies using similar but different and/or independent CD19 CAR vectors with similar structures, even though these were targeting the similar type of cells $[15,16,20,26,31,36-45]$. It is important to recognize that they should not be considered equal or interchangeable, neither should the outcomes from these studies be compared side by side since these were not randomized studies and there were multiple variables that were not directly comparable. For example, as shown in Table 1, there were differences in terms of EFS, OR, and CRS between the two CAR-T studies on R/R ALL, with the 19-41BB CAR-T having EFS and OS not reached. The EFS curve plateaus around 10 months in 19-41BB CAR trial, but there was no such plateau until 20 months on 19-28Z CAR-T trial. In addition, the 1 year EFS in 19-41BB CAR-T trial was 50\%, whereas the EFS was about $20 \%$ in the $19-28 Z$ CAR-T trial. It might seem that these results were quite different, though one should not directly compare them since the studies were not designed for the comparison, and there were multiple major differences, including patient populations, sample sizes, CAR constructs, and study center participations, as well as primary end points.

\section{Future perspectives}

Antibodies such as blinatumomab and IO are proven to be superior than the conventional chemotherapeutic agents for the adult R/R ALL. CAR-T cells appear to be very promising in further improving the therapeutic benefits in this population with very poor prognosis. However, these are still early phase studies with relatively small sample sizes and short follow-ups. Future studies such as the following are clearly needed:

1. Large prospective studies must be done to confirm the clinical efficacy
In the two large prospective randomized studies on adult R/R ALL, blinatumomab and IO were shown to extend median survival from under 6.7 to 7.7 months. Although it is not directly comparable, autologous CD-19-directed CAR-T cells were shown to lead to a median OS of 12.4 months in the $19-28 \mathrm{z}$ CAR study. For the phase II 19-41BB CAR study, the median overall survival has not been reached, and the median follow-up was only 13.1 months. As mentioned above, these results should not be compared directly. Large prospective studies must be done to confirm the clinical efficacy.

2. Moving CAR-T cell therapy to the front In the 19-28z CAR study, there was production failure of CAR-T cells in two subjects, and a total of 30 subjects failed to receive the CAR-T infusion, mostly due to advanced disease status. Therefore, it is conceivable that more patients could be treated with CAR-T cells if the therapy can be used earlier in the treatment planning.

3. Disease control should be optimized prior to CAR-T therapy

Disease burden prior to CAR-T infusion was shown to be the single most important factor to predict favorable outcome. It is therefore critical to optimize disease control and eliminate MRD prior to CAR-T cell therapy. This further supports the notion that CAR-T cell therapy should be used earlier as a consolidation regimen since better disease control may be achieved earlier in the course of consolidation/ salvage therapy. In addition, it is important to optimize the CAR-T cell dose so that better ratio of CAR-T cell dose to disease burden can be achieved.

4. Additional therapeutic modalities post CAR-T infusion should be explored All patients with MRD+CR and 50\% of those with MRD- CR relapsed after CAR-T cell therapy in the 19-28z CAR study. AlloSCT following CAR-T cell infusion in the patients with MRD-CR did not lead to better survival than those who were not transplanted. These intriguing observations suggest that therapeutic modalities other than AlloSCT post CAR-T cell therapy should be explored in order to achieve better long-term survival. Sequential and /or cocktail (concurrent) infusion of CAR-T cells targeting two or more different antigens are being explored $[16,46]$. To reinvigorate CAR-T cells, epigenetic modulation, and PD-1 antibodies are also being investigated [47]. Allogeneic CAR-T cells, including haplo-identical CAR-T and universal CAR-T cells, are being studied in clinical trials [35, 48]. These may be considered as alternative options for those patients with high risk of relapses after autologous CAR-T cell therapy. 


\section{Abbreviations}

ALL: Acute lymphoblastic leukemia; AlloSCT: Allogeneic stem cell transplantation; CAR: Chimeric antigen receptor; CRS: Cytokine release syndrome

\section{Acknowledgements}

This study was partly supported by The affiliated Cancer Hospital of Zhengzhou University and Henan Cancer Hospital.

\section{Funding}

This project was partly supported by the National Natural Science Foundation of China (NSFC grant no. 81470287, YPS).

\section{Availability of data and materials}

The material supporting the conclusion of this study has been included within the article.

\section{Authors' contributions}

DL designed the study. All authors drafted the manuscript. All authors read and approved the final manuscript.

\section{Ethics approval and consent to participate}

This is not applicable for this study.

\section{Consent for publication}

This is not applicable for this study.

\section{Competing interests}

The authors declare that they have no competing interests.

\section{Received: 13 February 2018 Accepted: 11 March 2018} Published online: 15 March 2018

\section{References}

1. Curran E, Stock W. How I treat acute lymphoblastic leukemia in older adolescents and young adults. Blood. 2015;125(24):3702-10.

2. Larson R, Dodge R, Burns C, Lee E, Stone R, Schulman P, Duggan D, Davey $F$, Sobol R, Frankel $S$. A five-drug remission induction regimen with intensive consolidation for adults with acute lymphoblastic leukemia: cancer and leukemia group B study 8811. Blood. 1995;85(8):2025-37.

3. Fielding AK, Richards SM, Chopra R, Lazarus HM, Litzow MR, Buck G, Durrant IJ, Luger SM, Marks DI, Franklin IM, McMillan AK, Tallman MS, Rowe JM Goldstone AH, Medical Research Council of the United Kingdom Adult ALLWP, Eastern Cooperative Oncology G. Outcome of 609 adults after relapse of acute lymphoblastic leukemia (ALL): an MRC UKALL12/ECOG 2993 study. Blood. 2007:109(3):944-50

4. Gökbuget N, Stanze D, Beck J, Diedrich H, Horst H-A, Hüttmann A, Kobbe G, Kreuzer K-A, Leimer L, Reichle A, Schaich M, Schwartz S, Serve H, Starck M, Stelljes M, Stuhlmann R, Viardot A, Wendelin K, Freund M, Hoelzer D. Outcome of relapsed adult lymphoblastic leukemia depends on response to salvage chemotherapy, prognostic factors, and performance of stem cell transplantation. Blood. 2012;120(10):2032-41.

5. Kantarjian HM, O'Brien S, Smith TL, Cortes J, Giles FJ, Beran M, Pierce S, Huh Y, Andreeff M, Koller C, Ha CS, Keating MJ, Murphy S, Freireich EJ. Results of treatment with hyper-CVAD, a dose-intensive regimen, in adult acute lymphocytic leukemia. J Clin Oncol. 2000;18(3):547-61.

6. Kantarjian HM, Thomas D, Ravandi F, Faderl S, Jabbour E, Garcia-Manero G, Pierce S, Shan J, Cortes J, O'Brien S. Defining the course and prognosis of adults with acute lymphocytic leukemia in first salvage after induction failure or short first remission duration. Cancer. 2010;116(24):5568-74.

7. O'Brien S, Thomas D, Ravandi F, Faderl S, Cortes J, Borthakur G, Pierce S, Garcia-Manero G, Kantarjian HM. Outcome of adults with acute lymphocytic leukemia after second salvage therapy. Cancer. 2008;113(11):3186-91.

8. O'Brien S, Thomas DA, Ravandi F, Faderl S, Pierce S, Kantarjian H. Results of the hyperfractionated cyclophosphamide, vincristine, doxorubicin, and dexamethasone regimen in elderly patients with acute lymphocytic leukemia. Cancer. 2008;113(8):2097-101.

9. Oriol A, Vives S, Hernandez-Rivas JM, Tormo M, Heras I, Rivas C, Bethencourt C, Moscardo F, Bueno J, Grande C, del Potro E, Guardia R, Brunet S, Bergua J, Bernal T, Moreno MJ Calvo C, Bastida P. Feliu E, Ribera JM, Programa Espanol de Tratamiento en Hematologia G. Outcome after relapse of acute lymphoblastic leukemia in adult patients included in four consecutive risk-adapted trials by the PETHEMA Study Group. Haematologica. 2010:95(4):589-96.

10. Topp MS, Gokbuget N, Stein AS, Zugmaier G, O'Brien S, Bargou RC, Dombret H, Fielding AK, Heffner L, Larson RA, Neumann S, Foa R, Litzow M, Ribera JM, Rambaldi A, Schiller G, Bruggemann M, Horst HA, Holland C, Jia C, Maniar T, Huber B, Nagorsen D, Forman SJ, Kantarjian HM. Safety and activity of blinatumomab for adult patients with relapsed or refractory Bprecursor acute lymphoblastic leukaemia: a multicentre, single-arm, phase 2 study. Lancet Oncol. 2014;16(1):57-66.

11. Kantarjian $H$, Stein A, Gokbuget $N$, Fielding AK, Schuh AC, Ribera JM, Wei A, Dombret H, Foa R, Bassan R, Arslan O, Sanz MA, Bergeron J, Demirkan F, Lech-Maranda E, Rambaldi A, Thomas X, Horst HA, Bruggemann M, Klapper W. Wood BL, Fleishman A, Nagorsen D, Holland C, Zimmerman Z, Topp MS. Blinatumomab versus chemotherapy for advanced acute lymphoblastic leukemia. N Engl J Med. 2017;376(9):836-47.

12. Kantarjian HM, DeAngelo DJ, Stelljes M, Martinelli G, Liedtke M, Stock W, Gokbuget N, O'Brien S, Wang K, Wang T, Paccagnella ML, Sleight B, Vandendries E, Advani AS. Inotuzumab ozogamicin versus standard therapy for acute lymphoblastic leukemia. N Engl J Med. 2016;375(8):740-53.

13. Sadelain M, Brentjens R, Riviere I. The promise and potential pitfalls of chimeric antigen receptors. Curr Opin Immunol. 2009;21(2):215-23.

14. Sadelain M, Brentjens R, Riviere I. The basic principles of chimeric antigen receptor design. Cancer Discov. 2013;3(4):388-98.

15. Sadelain M, Brentjens R, Riviere I, Park J. CD19 CAR therapy for acute lymphoblastic leukemia. Am Soc Clin Oncol Educ Book. 2015;33:e360-3.

16. Liu B, Song Y, Liu D. Clinical trials of CAR-T cells in China. J Hematol Oncol. 2017;10(1):166

17. Maude SL, Frey N, Shaw PA, Aplenc R, Barrett DM, Bunin NJ, Chew A, Gonzalez VE, Zheng Z, Lacey SF, Mahnke YD, Melenhorst JJ, Rheingold SR, Shen A, Teachey DT, Levine BL, June CH, Porter DL, Grupp SA. Chimeric antigen receptor $T$ cells for sustained remissions in leukemia. N Engl J Med. 2014:371(16):1507-17.

18. Ping Y, Liu C, Zhang Y. T-cell receptor-engineered T cells for cancer treatment: current status and future directions. Protein Cell. 2017:8 https://doi.org/10.1007/s13238-13016-10367-13231.

19. Wang Z, Wu Z, Liu Y, Han W. New development in CAR-T cell therapy. J Hematol Oncol. 2017;10(1):53.

20. Zhang C, Liu J, Zhong JF, Zhang X. Engineering CAR-T cells. Biomarker Research. 2017:5(1):22.

21. Zhang $E_{1} X \mathbf{X} H$. A new insight in chimeric antigen receptor-engineered $T$ cells for cancer immunotherapy. J Hematol Oncol. 2017;10(1):1.

22. Porter DL, Hwang WT, Frey NV, Lacey SF, Shaw PA, Loren AW, Bagg A, Marcucci KT, Shen A, Gonzalez V, Ambrose D, Grupp SA, Chew A, Zheng Z, Milone MC, Levine BL, Melenhorst JJ, June $\mathrm{CH}$. Chimeric antigen receptor $\mathrm{T}$ cells persist and induce sustained remissions in relapsed refractory chronic lymphocytic leukemia. Sci Transl Med. 2015;7(303):303ra139.

23. Porter DL, Kalos M, Zheng Z, Levine B, June C. Chimeric antigen receptor therapy for B-cell malignancies. J Cancer. 2011;2:331-2.

24. Porter DL, Levine BL, Kalos M, Bagg A, June $\mathrm{CH}$. Chimeric antigen receptormodified T cells in chronic lymphoid leukemia. N Engl J Med. 2011; 365(8):725-33.

25. Yu S, Li A, Liu Q, Li T, Yuan X, Han X, Wu K. Chimeric antigen receptor T cells: a novel therapy for solid tumors. J Hematol Oncol. 2017:10(1):78.

26. Grupp SA, Kalos M, Barrett D, Aplenc R, Porter DL, Rheingold SR, Teachey DT, Chew A, Hauck B, Wright JF, Milone MC, Levine BL, June CH. Chimeric antigen receptor-modified T cells for acute lymphoid leukemia. N Engl J Med. 2013;368(16):1509-18.

27. Wei G, Ding L, Wang J, Hu Y, Huang H. Advances of CD19-directed chimeric antigen receptor-modified $T$ cells in refractory/relapsed acute lymphoblastic leukemia. Experimental Hematology \& Oncology. 2017;6(1):10

28. Rosenbaum L. Tragedy, perseverance, and chance-the story of CAR-T therapy. N Engl J Med. 2017;377(0) https://doi.org/10.1056/NEJMp1711886.

29. Ribas A. Releasing the brakes on cancer immunotherapy. N Engl J Med. 2015:373(16):1490-2.

30. Locke FL, Neelapu SS, Bartlett NL, Siddiqi T, Chavez JC, Hosing CM, Ghobadi A, Budde LE, Bot A, Rossi JM, Jiang Y, Xue AX, Elias M, Aycock J, Wiezorek J, Go WY. Phase 1 results of ZUMA-1: a multicenter study of KTE-C19 antiCD19 CAR T cell therapy in refractory aggressive lymphoma. Mol Ther. 2017;25(1):285-95.

31. Park JH, Rivière I, Gonen M, Wang X Sénéchal B, Curran KJ Sauter C, Wang Y, Santomasso B, Mead E, Roshal M, Maslak P, Davila M, Brentjens RJ, 
Sadelain M. Long-term follow-up of CD19 CAR therapy in acute lymphoblastic leukemia. N Engl J Med. 2018;378:449-59.

32. Maude SL, Laetsch TW, Buechner J, Rives S, Boyer M, Bittencourt H, Bader P, Verneris MR, Stefanski HE, Myers GD, Qayed M, De Moerloose B, Hiramatsu H, Schlis K, Davis KL, Martin PL, Nemecek ER, Yanik GA, Peters C, Baruchel A, Boissel N, Mechinaud F, Balduzzi A, Krueger J, June CH, Levine BL, Wood P, Taran T, Leung M, Mueller KT, et al. Tisagenlecleucel in children and young adults with B-cell lymphoblastic leukemia. N Engl J Med. 2018;378(5):439-48,

33. Porter D, Frey N, Wood PA, Weng Y, Grupp SA. Grading of cytokine release syndrome associated with the CAR T cell therapy tisagenlecleucel. J Hematol Oncol. 2018:11(1):35.

34. Kohnke T, Krupka C, Tischer J, Knosel T, Subklewe M. Increase of PD-L1 expressing B-precursor ALL cells in a patient resistant to the CD19/CD3bispecific T cell engager antibody blinatumomab. J Hematol Oncol. 2015;8:111.

35. Cai B, Guo M, Wang Y, Zhang Y, Yang J, Guo Y, Dai H, Yu C, Sun Q, Qiao J, Hu K, Zuo H, Dong Z, Zhang Z, Feng M, Li B, Sun Y, Liu T, Liu Z, Wang Y, Huang Y, Yao B, Han W, Ai H. Co-infusion of haplo-identical CD19-chimeric antigen receptor T cells and stem cells achieved full donor engraftment in refractory acute lymphoblastic leukemia. J Hematol Oncol. 2016;9(1):131.

36. Hu Y, Sun J, Wu Z, Yu J, Cui Q, Pu C, Liang B, Luo Y, Shi J, Jin A, Xiao L, Huang $\mathrm{H}$. Predominant cerebral cytokine release syndrome in CD19directed chimeric antigen receptor-modified T cell therapy. J Hematol Oncol. 2016;9(1):70.

37. Liu J, Zhong JF, Zhang X, Zhang C. Allogeneic CD19-CAR-T cell infusion after allogeneic hematopoietic stem cell transplantation in B cell malignancies. J Hematol Oncol. 2017;10(1):35.

38. Neelapu SS, Locke FL, Bartlett NL, Lekakis L, Miklos D, Jacobson CA, Braunschweig I, Oluwole O, Siddiqi T, Lin Y, Timmerman J, Stiff PJ, Friedberg J, Flinn I, Goy A, Smith M, Deol A, Farooq U, McSweeney P, Munoz J, Avivi I, Castro JE, Westin JR, Chavez JC, Ghobadi A, Komanduri KV, Levy R, Jacobsen ED, Reagan P, Bot A, et al. Kte-C19 (anti-CD19 CAR T cells) induces complete remissions in patients with refractory diffuse large B-cell lymphoma (DLBCL): results from the pivotal phase 2 Zuma-1. Blood. 2016:128(22):LBA-6-LBA-6.

39. Qin L, Lai Y, Zhao R, Wei X, Weng J, Lai P, Li B, Lin S, Wang S, Wu Q, Liang Q, Li Y, Zhang X, Wu Y, Liu P, Yao Y, Pei D, Du X, Li P. Incorporation of a hinge domain improves the expansion of chimeric antigen receptor $\mathrm{T}$ cells. J Hematol Oncol. 2017;10(1):68

40. Turtle CJ, Hanafi LA, Berger C, Gooley TA, Cherian S, Hudecek M, Sommermeyer D, Melville K, Pender B, Budiarto TM, Robinson E, Steevens NN Chaney C, Soma L, Chen X, Yeung C, Wood B, Li D, Cao J, Heimfeld S, Jensen MC, Riddell SR, Maloney DG. CD19 CAR-T cells of defined CD4+:CD8+ composition in adult B cell ALL patients. J Clin Invest. 2016;126(6):2123-38.

41. Turtle CJ, Maloney DG. Clinical trials of CD19-targeted CAR-modified T cell therapy; a complex and varied landscape. Expert Rev Hematol. 2016;9(8):719-21.

42. Weng J, Lai $P$, Qin $L$, Lai $Y$, Jiang Z, Luo C, Huang $X$, Wu S, Shao D, Deng C, Huang L, Lu Z, Zhou M, Zeng L, Chen D, Wang Y, Chen X, Geng S, Robert W, Tang Z, He C, Li P, Du X. A novel generation 1928zT2 CAR T cells induce remission in extramedullary relapse of acute lymphoblastic leukemia. J Hematol Oncol. 2018;11(1):25

43. Xiao L, Huang H, Huang X, Ke X, Hu Y, Li J, Zhang Q, Hu Y, Jiang Q, Hu J, Jing $H$, Zhang $X$, Wu Z. Efficacy of anti-CD19 chimeric antigen receptor modified T(CAR-T) cell therapy in Chinese patients with relapsed/refractory acute lymphocytic leukemia in a multicenter trial. J Clin Oncol. 2017;35(15 suppl):7028.

44. Zhu Y, Tan Y, Ou R, Zhong Q, Zheng L, Du Y, Zhang Q, Huang J. Anti-CD19 chimeric antigen receptor-modified T cells for B-cell malignancies: a systematic review of efficacy and safety in clinical trials. Eur J Haematol. 2016;96(4):389-96.

45. Zhu YM, Wu Z, Tan YP, Du YY LZ, Ou RM, Liu S, Pu CF, Jiang J, Wang JP, Xiao L, Zhang Q. Anti-CD19 chimeric antigen receptor T-cell therapy for adult Philadelphia chromosome-positive acute lymphoblastic leukemia: two case reports. Medicine (Baltimore). 2016;95(51):e5676.

46. K-c F, Guo Y-I, Liu Y, Dai H-r, Wang Y, Lv H-y, Huang J-h, Yang Q-M, Han Wd. Cocktail treatment with EGFR-specific and CD133-specific chimeric antigen receptor-modified $T$ cells in a patient with advanced cholangiocarcinoma. J Hematol Oncol. 2017;10(1):4.

47. Chong EA, Melenhorst JJ, Lacey SF, Ambrose DE, Gonzalez V, Levine BL, June $\mathrm{CH}$, Schuster SJ. PD-1 blockade modulates chimeric antigen receptor (CAR)—-modified T cells: refueling the CAR. Blood. 2017;129(8):1039-41.
48. Qasim W, Zhan H, Samarasinghe S, Adams S, Amrolia P, Stafford S, Butler K, Rivat C, Wright G, Somana K, Ghorashian S, Pinner D, Ahsan G, Gilmour K, Lucchini G, Inglott S, Mifsud W, Chiesa R, Peggs KS, Chan L, Farzeneh F, Thrasher AJ, Vora A, Pule M, Veys P. Molecular remission of infant B-ALL after infusion of universal TALEN gene-edited CAR T cells. Sci Transl Med. 2017;9(374) https://doi.org/10.1126/scitranslmed.aaj2013.

\section{Submit your next manuscript to BioMed Central and we will help you at every step:}

- We accept pre-submission inquiries

- Our selector tool helps you to find the most relevant journal

- We provide round the clock customer support

- Convenient online submission

- Thorough peer review

- Inclusion in PubMed and all major indexing services

- Maximum visibility for your research

Submit your manuscript at www.biomedcentral.com/submit
( Biomed Central 